\title{
NUSA PENIDA MARINE PROTECTED AREA (MPA) \\ BALI - INDONESIA: WHY NEED TO BE PROTECTED?
}

\author{
Toni RUCHIMAT *, Riyanto BASUKI *and Marthen WELLY**
}

* Directorate of Marine and Aquatic Species Conservation, Ministry of Marine Affair and Fisheries, truchimat@yahoo.com, riyanbas@yahoo.com

** Coral Triangle Center (CTC), mwelly@coraltriangle.org

KEYWORDS: marine protected area, biodiversity, Nusa Penida.

\begin{abstract}
Nusa Penida comprises a group of islands in the south-east of Bali. This archipelago contains a high level of marine biodiversity and has significant tourism potential. In addition, Nusa Penida has aquaculture and fishing areas, which continue to be developed. Efforts towards conservation and sustainable use by means of Marine Protected Areas (MPAs) provide an important solution to counteract increasing pressure on natural resources due to economic activities. Zoning system arrangements to protect marine biodiversity, as well as sustainable economic activities, form the highest priority in the management of the Nusa Penida MPA.

The paper provides an overview of the coastal ecosystem of Nusa Penida and the potential for sustainable utilization of natural resources, as well as demonstrates the socioeconomic condition of the Nusa Penida community. Rapid Ecological Assessment (REA) in 2009 for the marine ecosystems in the waters of Nusa Penida serves as baseline data to provide inputs for defining the MPA, including a zoning system and a management plan.

The ecological survey revealed 1,419 ha of coral reef with 296 species, 230 ha of mangrove with 13 species, and 108 ha of seagrass beds with 8 species. The assessment of fish biodiversity revealed 296 species of fish, including five that are new to science. Nusa Penida's waters are home to marine megafauna such as sea turtles, sharks and cetaceans, also unique and charismatic fish such as ocean sunfish (Mola mola) and manta rays (Manta birostris), that occur predictably annually.

Marine tourism, seaweed farming and capture fisheries are the main economic activities for the income of the coastal community. Nusa Penida is visited by more than 200,000 tourists each year. The tourists dive in 20 dive-spots arround the waters. There are 308 ha of seaweed farming that produce more than 50 tons per month. About 850 local fishermen depend for their livelihood on the fishing grounds around the waters of Nusa Penida for their livelihood. In total, some 46,000 residents depend on the marine biodiversity of the archipelago for their livelihood.

Destructive fishing and over-fishing are serious threats to the reef ecosystem within the Nusa Penida MPA, as well as to the sustainable fisheries. The lack of a clear zoning system and its attendant regulation of uses for Nusa Penida's coastal area and marine resources mean potential conflicts between marine tourism, seaweed farming and the fisheries. The establishment of the MPA with a management plan is imperative to regulate the sustainable use of marine resources.
\end{abstract}


RÉSUMÉ: La zone marine de protection (MPA) de Nusa Penida Bali - Indonésie: Pourquoi la protéger?

Nusa Penida fait partie d'un petit groupe d'îles situées au sud-ouest de Bali. Cet archipel abrite une grande biodiversité marine et a un potentiel touristique important. De plus, à Nusa Penida on pratique l'aquaculture et la pêche qui connaissent un important essor. Les efforts de conservation et d'utilisation durable des ressources marines à l'aide de l'MPA sont devenus une solution non-négligeable devant la pression croissante exercée par les activités économiques sur les ressources naturelles. Les aménagements du système de zonage pour la protection de la biodiversité marine ainsi que pour le soutien des activités économiques sont hautement prioritaires dans la gestion d'MPA Nusa Penida.

Cet article se propose d'offrir une vue d'ensemble sur l'écosystème côtier de Nusa Penida et de la potentielle utilisation durable des ressources naturelles mais aussi de présenter le contexte socio-économique de la communauté locale. L'Evaluation Ecologique Rapide (REA) de l'écosystème marin qui a eu lieu en 2009, sert en tant que donnée de départ pour l'établissement du système de zonage, y compris pour la MPA et pour le plan de gestion.

L'étude écologique a montré que la zone récifale couvre une surface de 1419 ha et contient 296 espèces de coraux; les mangroves sont formées par 13 espèces couvrant 230 ha et l'herbier couvre 108 ha et contient 8 espèces d'herbe de mer. L'évaluation de la biodiversité des poissons a révélé 296 espèces parmi lesquelles 5 qui sont des espèces nouvelles pour la science. Les eaux environnantes abritent une mégafaune marine formée de tortues de mer, de requins, de cétacés ainsi que l'unique et charismatique poisson lune (Mola mola) et des raies manta (Manta birostris) dont l'apparition reste prédictible et annuelle.

Le tourisme marin, les fermes d'herbe de mer et la pêche sont les principales activités économiques assurant le revenu de la communauté côtière. Nusa Penida accueille plus de 200 000 touristes chaque année. Les touristes font de la plongée au niveau de 20 points autour de l'île. Les 308 hectares cultivés à l'herbe de mer produisent environ 50 tonnes par mois. Environ 850 pêcheurs gagnent leur vie en exploitant les terrains de pêche autour de Nusa Penida. A peu près 46000 habitants gagnent leur vie aux dépens de la biodiversité marine de Nusa Penida.

La pêche destructive et la surpêche sont des menaces sérieuses pour l'écosystème du récif de la MPA Nusa Penida ainsi que pour les activités de pêche durable. Le manque d'un système clair de zonage et de réglementation d'usage pour la zone côtière de Nusa Penida et pour les ressources marines créent les prémisses d'un potentiel conflit entre le tourisme marin, les fermes d'herbe de mer et les activités de pêche. La mise en place de la MPA et la rédaction de son plan de gestion sont impératives afin de permettre une utilisation durable des ressources marines.

REZUMAT: Zona de protecție marină (MPA) Nusa Penida Bali - Indonezia: De ce este nevoie de protecție?

Nusa Penida face parte dintr-un grup de insule situat în sud-estul insulei Bali. Acest arhipelag conține un grad mare de diversitate a vieții marine și are un potențial turistic însemnat. În plus, Nusa Penida are activităţi de acvacultură și pescuit care continuă să se dezvolte. Eforturile de conservare și utilizare durabilă a resurselor marine cu ajutorul MPA au devenit o soluție importantă în fața presiunii tot mai mari exercitate de activitățile economice asupra resurselor naturale. Amenajarea sistemului de zonare pentru protejarea biodiversității marine precum și susținerea activităților economice sunt de cea mai mare prioritate în gestionarea MPA Nusa Penida. 
Acest articol își propune să ofere o vedere de ansamblu asupra ecosistemelor costiere de la Nusa Penida și asupra potențialului utilizării sustenabile a resurselor naturale precum și să arate contextul socio-economic al comunității din Nusa Penida. Evaluarea Ecologică Rapidă (REA) a ecosistemului marin din apele din jurul insulei, ce a avut loc în 2009 a oferit datele de plecare pentru stabilirea sistemului de zonare inclusiv pentru MPA și pentru redactarea planului de management.

Studiul ecologic a arătat că zona de recif acoperă o suprafață de 1.419 ha și conține 296 specii de corali, mangrovele sunt formate din 13 specii pe 230 ha iar zona de pajiște submarină acoperă 108 ha și conține 8 specii de iarbă de mare. Evaluarea biodiversității piscicole a descoperit existența a 296 specii de pești din care 5 sunt specii noi pentru știință. Apele din jurul Nusa Penida găzduiesc o mega faună marină formată din țestoase marine, rechini, cetacee, precum și peștele soare, atât de unic și carismatic (Mola mola) și diavoli de mare (Manta birostris) a căror apariție este predictibilă și anuală.

Turismul marin, creșterea ierburilor de mare și pescuitul sunt principalele activități economice desfăşurate de comunitatea costieră de pe Nusa Penida. Insula are peste 200.000 turiști anual. Aceștia practică scufundări în 20 de puncte situate în proximitatea insulei. Fermele de iarbă de mare acoperă 308 ha și produc peste 50 tone/lună. În jur de 850 de pescari locali depind pentru hrana zilnică de peștele din jurul insulei. Biodiveristatea marină asigură traiul zilnic pentru aproximativ 46.000 localnici din Nusa Penida.

Pescuitul distructiv și supraexploatarea sunt amenințări serioase pentru ecosistemele de recif din MPA Nusa Penida precum și pentru pescăriile durabile. Lipsa unui sistem de zonare clar și a regulamentului pentru utilizările zonei costiere și a resurselor marine din Nusa Penida duc la conflicte potențiale între turismul marin, fermele de iarbă de mare și activitățile piscicole. Stabilirea și punerea în aplicare a planului de management al MPA sunt imperative pentru reglementarea utilizării sustenabile a resurselor marine locale.

\section{INTRODUCTION}

The Indonesian government is committed to protect the coastal and marine area of about 20 million hectares by 2020. This commitment also parallels with the Coral Triangle Initiative (CTI) where Indonesia is already appointed as CTI secretariat. Currently, the Ministry of Marine Affairs and Fisheries (MMAF) in collaboration with provincial, district and community authorities, NGOs and universities are already establishing 13.9 million hectares of marine protected area (MPA) to sustain Indonesia, including coral triangle marine biodiversity.

The Nusa Penida Marine Protected Area (Penida MPA) is one of the MPA that lies just a few kilometres south-east of Bali-Indonesia and within the Coral Triangle - an area of exceptional marine biodiversity. The total area of Nusa Penida MPA is 20.057 hectares that covers water surrounding the Penida, Ceningan and Lembongan islands. The Minister of Marine Affair and Fisheries together with the Bali Governor and Head of Klungkung District declared Nusa Penida MPA in November 2010. The MPA is legalized under the Klungkung District Decree no. 12/2010.

\section{Marine Biodiversity}

Based on the ecological surveys of 2002-2009 period, 1,419 hectares of coral reef, 230 hectares of mangrove with 13 species and 108 hectares of seagrass bed with 8 species were found in Nusa Penida (Sanjaya, 2009). Furthermore, a marine rapid ecological assessment (REA) in Nusa Penida's water found 296 species of coral reef (Turak and Vantier, 2009). There is also a tremendous fish biodiversity; the REA found 576 species of fish, five of which 
are new species (Allen and Erdmann, 2008). Nusa Penida water bodies are also home to unique marine mega-fauna such as sea turtles, sharks, whales, and dolphins.

The water bodies of Nusa Penida are world-famous for aggregations of ocean sunfish (Mola mola) and manta rays (Manta birostris) that occur predictably on the south coast of Penida each year. The ocean sunfish season is between July-September and divers can find manta rays during this period of the year. Whales and dolphins also migrate through the straits to the east and west of the island.

However, the Nusa Penida's coastal area is intensively used for economic activities such as seaweed farming, marine tourism and fisheries. Nusa Penida has 20 dive spots around Nusa Penida water bodies, with more than 200,000 tourists visiting Nusa Penida each year. There are 308 hectares of seaweed farming area with an average production of about 50 tons/month.

Nusa Penida water bodies also serve as fishing grounds for almost 900 local fishermen. Snapper, grouper, travelly and other reef fish are common fish that are found there. More than 46,000 residents depend on the marine biodiversity in Nusa Penida for their day by day survival (Sanjaya, 2009).

Regarding the climate changes issue, based on regular sea-temperature observation, the water temperature ranges between $14-31^{\circ} \mathrm{C}$. Fortunately, there is no "coral bleaching" event recorded till now in Nusa Penida. The local coral communities are maybe more resilient to "coral bleaching" due to the local cold water upwelling's - creating a coral refuge during warm water episodes (CTC, 2010).

\section{Socioculture of the community}

Nusa Penida is a part of the Klungkung District administration, Bali Province. This sub-district includes three major islands, Nusa Penida, Nusa Lembongan and Nusa Ceningan, with a total area of about 20,000 hectares. There are 46,000 people who inhabit the 16 administrative villages and 40 pakraman villages in Nusa Penida.

The main livelihood sources in Nusa Penida are seaweed farming, fisheries, marine tourism, livestock and farming. There are four high schools and three junior high schools on these islands. Out of the $90 \mathrm{~km}$ coastline of Klungkung District, $70 \mathrm{~km}$ are part of Nusa Penida, while the rest are located in the mainland.

The majority of the Nusa Penida community belongs to the Balinese with Hindu religion. The temple of Sad-Khayangan Ped in Nusa Penida is one of the central temples of Bali. Nusa Penida has several big-temples, such as Batu Medau and Giri Putri temple. Puncak Mundi is the highest point in Nusa Penida where another temple is located, that is frequently visited by the Nusa Penida community and the Balinese from the mainland, for prayers.

The traditional structure that overlooks pakraman villages in Nusa Penida is the Alit Assembly. The assembly coordinates, performs and supervises religious and customary rituals. The community of Nusa Penida also performs the Nyepi Segara ritual every year to honour the sea. The ritual is usually held on sasih kapat, which falls on October. During Nyepi Segara, fishing activity in the sea is not allowed for a full day.

\section{Economic activities}

Marine Tourism. Over 20 diving sites are distributed around the water of Nusa Penida. Crystal Bay, Manta Point, Ceningan Wall, Blue Corner, SD-Sental, Mangrove-Sakenan, Gamat Bay and Batu Abah are favorite diving sites in Nusa Penida. Three major cruises give an attractive daily trip to Nusa Penida for about 600 tourists, with their own pontoon facility. 
Marine tourism attractions in Nusa Penida include diving, surfing, snorkelling, sailing, fishing, flying-fish, para-sailing, kayaking and sea-walking. There are six diving operators based in Nusa Lembongan and Nusa Penida. About 200,000 tourists visit Nusa Penida every year. The peak season usually falls in August and September, while the low season falls in January and February.

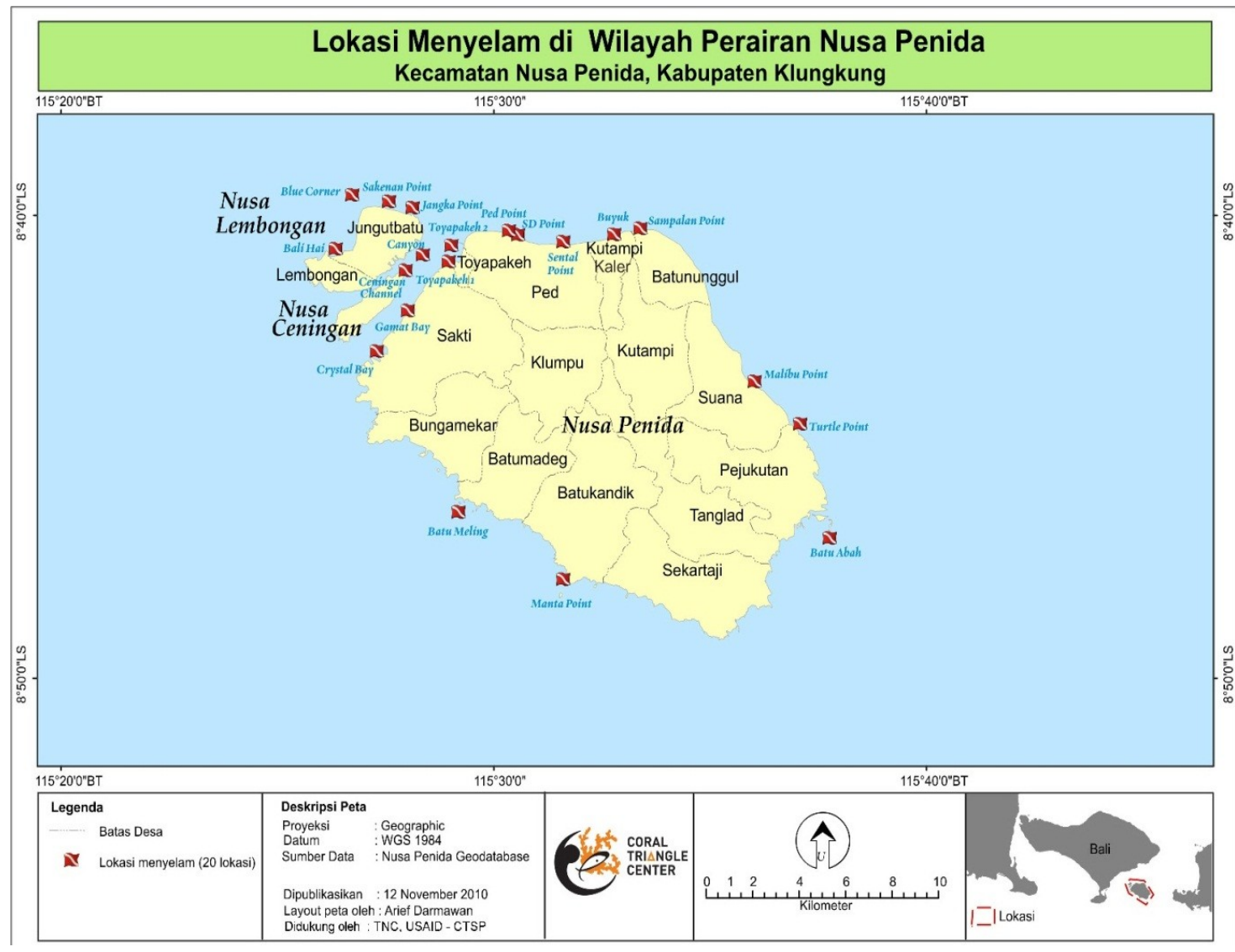

Figure 1: Diving sites in Nusa Penida.

Seaweed Cultivation. Nusa Penida has approximately 308 hectares with maximum potential for seaweed cultivation (Sanjaya, 2009). The used seaweed farming method is the line-culture technique. Euchema spinossum is the most abundantly grown seaweed in Nusa Penida and specifically in Lembongan, Euchema cotonii grows well in the strait between Lembongan and Ceningan. Seaweed farmers in Nusa Penida are able to harvest an average of about 40-50 tons per harvest cycle (every 35 days). Market price fluctuates significantly, the current price for a kilogram of Spinossum with $30 \%$ water content is 2,000-2,900 Rp. In contrast, the Cotonii can reach about 4,000-5,300 Rp. per kilogram.

The average net-income from 1 acre $(10 \mathrm{~m} \times 10 \mathrm{~m})$ plot of seaweed is around 300,000 Rp. Middlemen coordinate the seaweed sales and send them to Surabaya before being exported to China, Taiwan, Korea and Japan. 


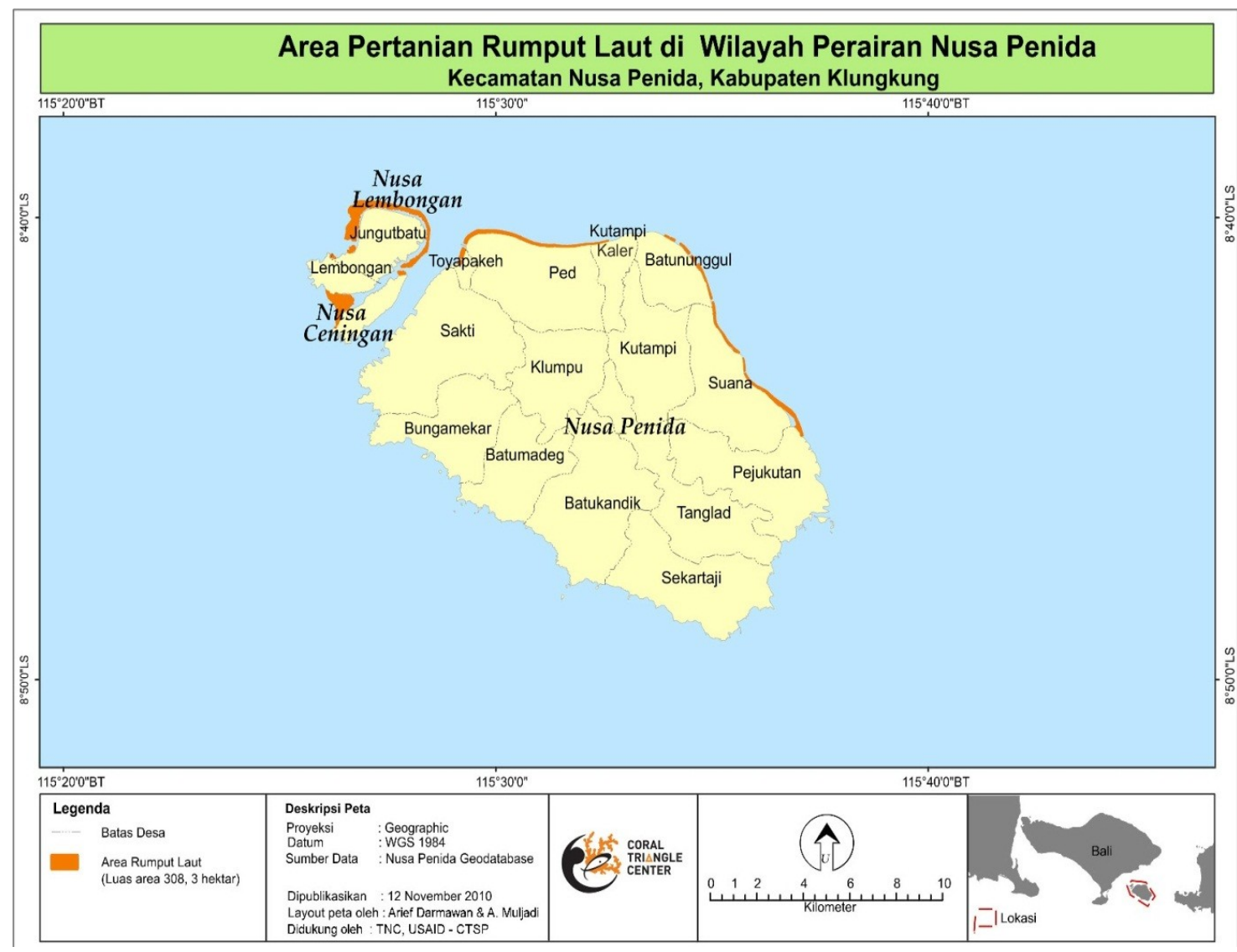

Figure 2: Seaweed farming area in Nusa Penida sub-district.

Fisheries. About 850 fishermen live in the Nusa Penida sub-district who are divided into 40 fishermen groups.

Batununggul and Suana villages have the largest number of fishermen. Most fishermen in Nusa Penida are using seven meter fishing boats with 15 PK outboard engines power. Usually, the fishing grounds are located mostly between 40-200 meters in water depth, with a distance range of 5 miles from the mainland, even reaching Lombok.

In general, the fishermen catch fishes such as Auxis spp., lutjanidae, grouper/ ephinepelus, sharks/elasmobranch, skipjack/katsuwonus pelamis and other species depending on the season.

Fishermen usually depart at dawn and return later in the morning.

Prices for a medium-sized skipjack range from 3,000-5,000/fish Rp.

Fishing grounds of consumption of fish for local people such as grouper and other reef fish are found in the north and west of Nusa Penida. 


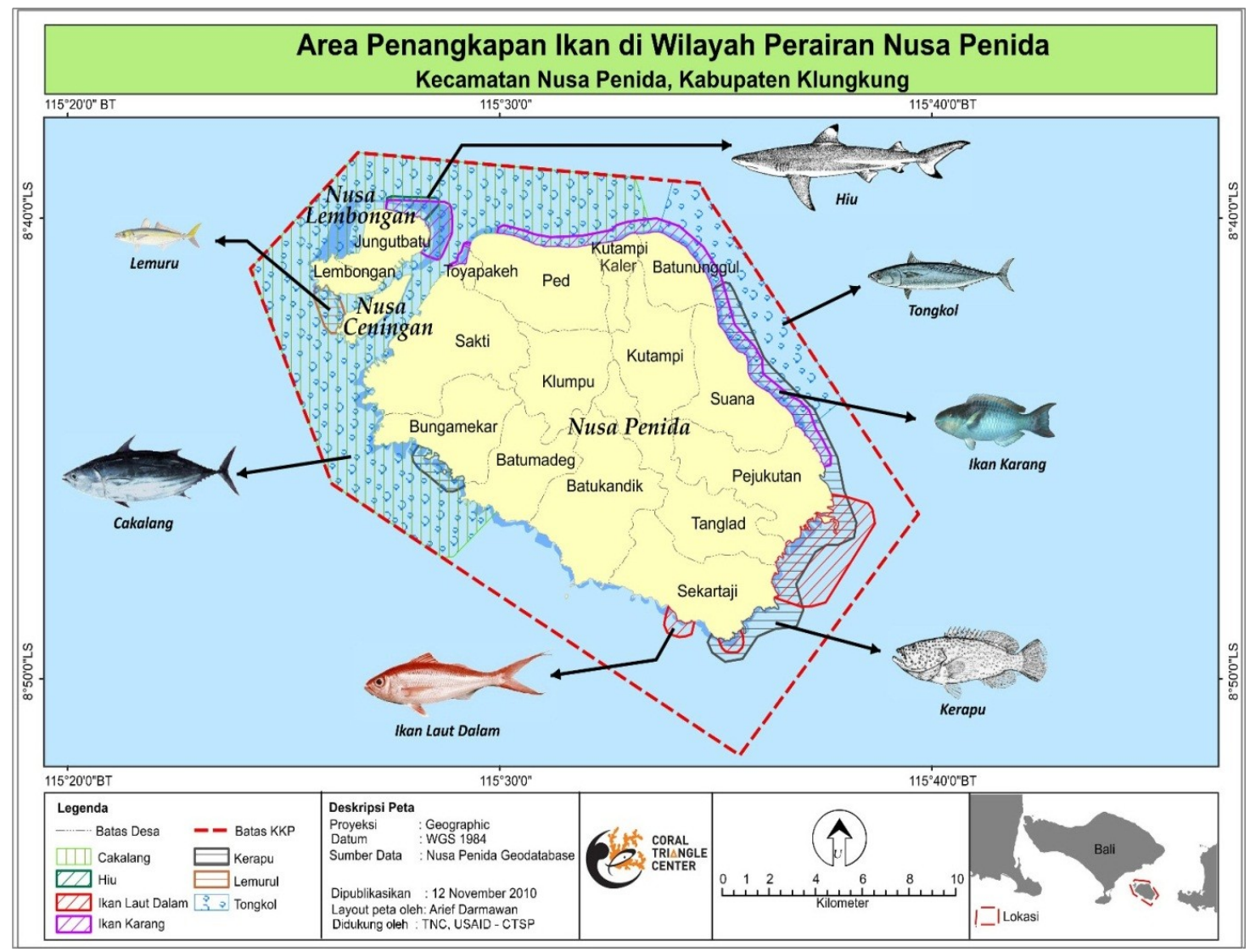

Figure 3: Fishing grounds around Nusa Penida.

\section{Threats to Nusa Penida Marine Biodiversity}

Unfortunately, the tremendous Nusa Penida marine biodiversity is facing threats from human activities and nature's dynamics. Destructive fishing (poison and bom fishing) and overfishing pose a serious threat to the reef ecosystems of the proposed Penida MPA and sustainable fisheries.

Local communities of Nusa Penida rely on these reefs as an income and livelihood source - directly through fishing and seaweed farming, and indirectly through the expanding marine tourism industry which provides employment opportunities. While tourism development offers opportunities for local communities, it is important to ensure that the environmental values of the area are not compromised.

The lack of a clear marine zoning system and regulation of the uses in Nusa Penida's coastal area and marine resources can create potential conflicts between marine tourism, seaweed farming and fisheries activities.

The region's marine biodiversity is under threat of over-exploitation, which would mean that it could no longer sustain ecosystem services for local people's livelihood. 


\section{MPA as a Long-Term Solution}

For sustaining the marine biodiversity in Nusa Penida area that would bring benefits to the local people, the Ministry of Marine Affairs and Fisheries (MMAF) in collaboration with the Klungkung District Government and Coral Triangle Center (CTC) - an Indonesia's NGO focused on capacity building within the coral triangle region and have supported an establishment of collaborative management, the Marine Protected Area (MPA).

The Nusa Penida MPA establishment initiative itself has three objectives: 1) marine biodiversity protection; 2) sustainability in fisheries and 3) sustainability in marine tourism. The objectives are meant to guarantee the local community's livelihood from marine resources.

The establishment of Nusa Penida MPA is based on scientific evidences, as well as law and regulation guidance such as the Ministery of Marine Affairs and Fisheries Decree no. 2/ 2009 regarding MPA Establishment Procedures and Decree no. 30/2010 regarding the MPA Management Plan and Zoning System. The MPA establishment approach combines a topdown and bottom-up approach to accommodate proportionally the interests of key stakeholders.

Public consultation with Nusa Penida key stakeholders was done to get inputs and development agreements on the Nusa Penida MPA establishment through 33 meetings at Focus Groud Disscusion (FGD), village, sub-district and district levels. More than 1,200 participants among them like fishermen, seaweed farmers, marine tour operators, district and sub-district government officials, teachers, students and traditional leaders involved actively and the majority showed support for the MPA establishment.

As follows-up on the agreement from Nusa Penida's key stakeholders, the Klungkung District Government has established Nusa Penida MPA Task-Force that consists of an official government local agency, community group representatives and NGOs representatives that work under the Head of the Klungkung District Decree no. 216/2009. The Task-Force's main objective is to do preparations for the Nusa Penida MPA launch. In November 2010, the Minister of Marine Affairs, together with the Bali Governor and Head of Klungkung District launched the MPA.

This year, Nusa Penida MPA is in the process of developing a zoning system, a 20 years management plan, as well as a management body, including a joint patrol before the proposal of getting a Ministerial Decree. For the time being, CTC in collaboration with the Brawijaya University have already developed a marine tourism profile in Nusa Penida as inputs on sustainable financing mechanism for Nusa Penida MPA. Study on willingness to pay will be conducted in October to find out how many visitors or tourists would contribute with an entrance fee and conservation fund. If all the instruments that are needed for Nusa Penida MPA are set in place and fully operated, hopefully the MPA will effectively work to sustain the local community's source of livelihood.

\section{Zoning system in Nusa Penida MPA}

The development of the zoning system in Nusa Penida MPA is based on ecological and socioeconomic baseline data, as well as public consultation inputs and policy assessment. According to the Minister of Marine Affairs and Fisheries Decree no. 30/2010, an MPA should consist of a core zone, a sustainable fisheries zone, an utilization zone and other zones. The core zone is about $2 \%$ of the total area of the MPA.

As a result of the public consultation through 14 meetings at Focus Group Disscusion (FGD), village and sub-district levels along with fishermen, seaweed farmers, traditional leaders, dive operators, heads of villages and sub-districts and the key stakeholders, in Nusa Penida agreed on a core zone, sustainable fisheries zone, marine tourism zone, seaweed 
farming zone, and holy zone in front of a temple in the coastal areas. From a total of 20,057 hectares of the Nusa Penida MPA, the sustainable fisheries zone is about 17,000 hectares, which is about $80 \%$ of the Nusa Penida MPA. In contrast, the no take zone (core zone and marine tourism zone) is about $20 \%$ of the critical habitat.

The regulations for each zone are 1) core zone - fisheries and marine tourism activities are allowed, limited research and education activities with permit are allowed, 2) marine tourism zone - fishing is not allowed in this zone, marine tourism activities are allowed, 3) sustainable fisheries zone - fishermen can perform fishing activities in this zone with no destructive methods and fishing gear, compressor-hookah is not allowed in this zone based on local fishermen is request, 4) seaweed farming zone - this zone is only for seaweed farming, fishing with traditional gear such as pole and line, small net and traditional spear-gun are allowed, 5) holy zone for temple - boat parking, especially diving boats are not allowed in front of the temple since sometimes tourists have inappropriate dressing, before and after diving, but diving activities in front of the temple are allowed.

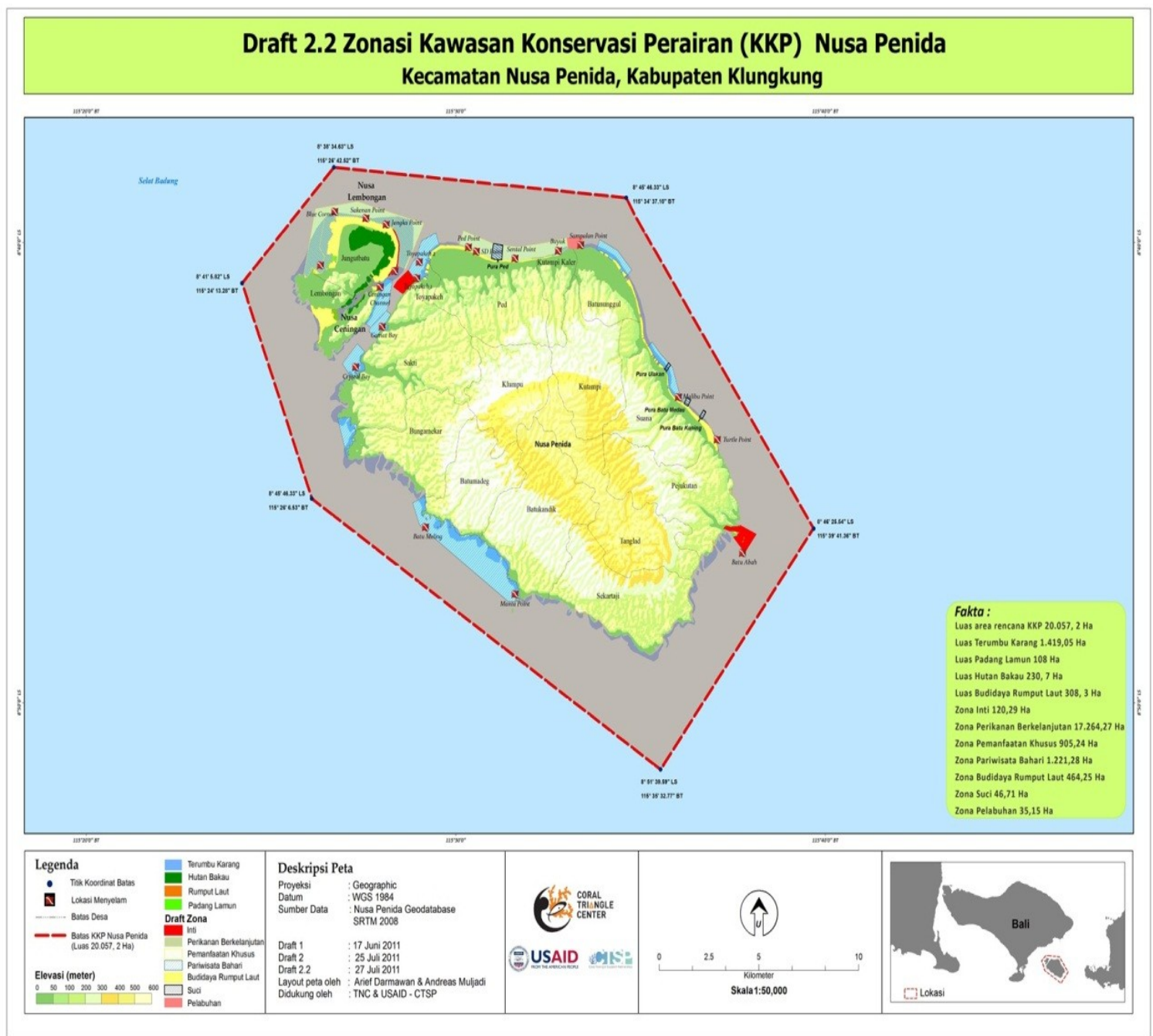

Figure 4: Nusa Penida MPA with Outer Boundary and Draft of Zoning System. 


\section{REFERENCES}

1. Allen G. R. and Erdman M. V., 2008 - Reef Fish of Nusa Penida, Indonesia, Final Report to Conservation International, 22.

2. Sanjaya W., 2009 - Monitoring Terumbu Karang dan Ikan Nusa Penida, Dinas Peternakan, Perikanan dan Kelautan (DPPK) Klungkung, Yayasan Bahtera Nusantara, The Nature Conservancy Indonesia Marine Program (TNC-IMP), 64.

3. Turak E. and De Vantier L., 2009 - Biodiversity and Conservation Priorities of Reef-Building Corals in Nusa Penida, Final Report to Conservation International, 66. 